\title{
Preliminary Study on Morphological Diversity of Aspergillus niger Strains Grown on Various Agri - waste in Relation to Enzyme Production
}

\author{
Neeta Raj Sharma*, Anupama Sasankan and Giridhar Soni \\ Department of Biotechnology, Lovely School of Sciences, Lovely Professional University, Phagwara, Punjab, India
}

\begin{abstract}
The present investigation was aimed to observe the correlation of morphology of various isolates of Aspergillus niger on the production of Polygalacturonase (PG) and Pectin Methyl Esterase (PME) with the concept to develop a screening procedure for high enzyme producing strains of Aspergillus niger grown on agri waste. The strains were isolated from orange peel, tamarind seed powder, groundnut, carrot, pomegranate peel and apple baggasse, soil, waste water and bread. The maximum enzyme activity (PG: $2.20 \pm 0.05 \mu \mathrm{moles} / \mathrm{ml} / \mathrm{min} \&$ PME: $0.73 \pm 0.08 \mu \mathrm{moles} /$ $\mathrm{ml} / \mathrm{min}$ ) was observed with the smallest spore size of Aspergillus niger obtained from orange peel $(5.49 \pm 2.56 \mu \mathrm{m})$. However, no correlation of conidiophore size, height of conidial stalk on pectinase production was noted. There is no report found on the level of pectinases in strain of Aspergillus niger grown on tamarind seed powder which showed considerable amount of pectinases in present study.
\end{abstract}

Keywords: Polygalacturonase; Pectin methyl esterase; Aspergillus niger; Morphological diversity

\section{Introduction}

Pectins are high molecular weight acid polysaccharides, primarily made up of $\alpha-(1-4)$ linked D-galacturonicacid residues with a small number of rhamnose residues in the main chain and arabinose, galactose and xylose on its side chain [1]. Pectinase is a generic name for a family of enzymes that catalyse hydrolysis of the glycosidic bonds in the pectic polymers [21]. Pectinases include polygalacturonase (EC3.2.1.15). Pectinase is used in the extraction, clarification, filtration, and depectinization of fruit juices [10] and wines, for the maceration of fruits and vegetables, removal of the inner wall of lotus seed, garlic, almond, and peanut [1]. Pectinase plays the role of degrading pectinic substances. An important consideration for the food processing industry is the cost efficiency of pectinase production [13]. Filamentous fungi are important in industrial enzyme production, since they are able to synthesize and secrete large amounts of extra cellular proteins. The importance of morphological and physiological studies on fungi in liquid cultures has been recently reviewed [5] Fungal macro- and micro-morphology affect the rheology of the fermentation medium, thereby having a significant impact on the mixing, mass transfer and aeration processes within the bioreactor. In addition, micromorphology may influence metabolite productivity, which may lead to lower net specific growth rate [8] or to enhanced enzyme production by strains with altered morphology [11] However, few criteria about fungal physiology and morphology in solid-state cultures have been established in the limited studies available. For instance, working with Neurospora crassa in solid culture defined the hyphal growth unit (total hyphal length/number of hyphal tips) as a measurement of the fungal invasive capacity [24]. In contrast, the colony radial extension rate obtained by linear regression of colony diameter versus time [7]. Black Aspergillus, which comprises of species belonging to Aspergillus section Nigri, are worldwide distributed and have a significant impact on modern society. Many species cause food spoilage, and several are used in the fermentation industry [6]. A. niger has even been granted the GRAS (Generally Regarded As Safe) status in certain industrial production processes by the Food and Drug Administration of the US government [18]. Various reports evidenced that members of the $A$. niger species complex, together with A. carbonarius and A. japonicus/ aculeatus are frequently responsible for post-harvest decay of fresh fruit (apples, pears, peaches, citrus, grapes, figs, strawberries, tomatoes, melons, etc.) and some vegetables (especially onions, garlic, and yams) [20]. Studies suggest that Black Aspergilli are one of the most difficult groups concerning classification and identification [3]. The taxonomy of Aspergillus section Nigri has been studied by many taxonomists, leading to various species concepts. The difficulties in species recognition within the Aspergillus niger "aggregate" and the fact that most of the studies carried out on black Aspergilli occurring on grapes lack molecular characterization of the strains perplexed the extent of their natural occurrence and species distribution on grapes and food [3]. Studies on the biodiversity of toxigenic Aspergillus species is useful to clarify molecular, ecological and biochemical characteristics of the different species in relation to their different adaptation to environmental and geographical conditions, and to their potential toxigenicity [19]. A. niger is also an important model organism for several important research areas including the study of eukaryotic protein secretion in general, the effects of various environmental factors on suppressing or triggering the export of various biomass degrading enzymes, molecular mechanisms critical to fermentation process development, and mechanisms involved in the control of fungal morphology $[17,18]$. The genetic diversity within $A$. flavus populations has been widely studied in relation to their potential aflatoxigenicity and morphological variants L- and S-strains. Within A. flavus and other Aspergillus species capable of aflatoxin production, considerable diversity is found.

In present study effort has been made to determine possible

*Corresponding author: Dr. Neeta Raj Sharma, Department of Biotechnology, Lovely School of Sciences, Lovely Professional University, Phagwara, Punjab, India, Tel: +91-9316645414; E-mail: neeta.raj@Ipu.co.in

Received August 04, 2011; Accepted October 17, 2011; Published October 22, 2011

Citation: Sharma NR, Sasankan A, Soni G (2011) Preliminary Study on Morphological Diversity of Aspergillus niger Strains Grown on Various Agri - waste in Relation to Enzyme Production. J Microbial Biochem Technol 3: 084-087. doi:10.4172/1948-5948.1000056

Copyright: (c) 2011 Sharma NR, et al. This is an open-access article distributed under the terms of the Creative Commons Attribution License, which permits unrestricted use, distribution, and reproduction in any medium, provided the original author and source are credited 
Citation: Sharma NR, Sasankan A, Soni G (2011) Preliminary Study on Morphological Diversity of Aspergillus niger Strains Grown on Various Agri waste in Relation to Enzyme Production. J Microbial Biochem Technol 3: 084-087. doi:10.4172/1948-5948.1000056

relationship between morphological diversity of Aspergillus niger and production of Pectinases, keeping in view to develop simple methods for identification of maximum enzyme producing strains.

\section{Material and Methods}

The present investigation was started in the month of December 2009 at Department of Biotechnology, Lovely School of Sciences, Lovely Professional University, Phagwara, Punjab, India and accomplished in July 2010.

\section{Isolation of microorganism}

Aspergillus niger was isolated from various sources such as orange peel, tamarind seed powder, apple baggasse, pomegranate, carrot, groundnut, soil, waste water and bread. These samples were especially collected from the rotten fruits, grocery market of Jalandhar, Phagwara and campus of Lovely Professional University, Punjab.

Sources and Culture maintenance of microorganism for enzyme production: Nine solid substrates were used in this study such as orange peel, pomegranate peel, tamarind seed powder, carrot, groundnut, soil, waste water, apple baggasse and bread. These cultures were maintained and sub cultured under aseptic conditions on Potato Dextrose Agar (PDA) slants and stored at $4^{\circ} \mathrm{C}$ in the laboratory of Department of Biotechnology, Lovely professional University Phagwara, Punjab, India. The fungal cultures were grown on PDA at $30^{\circ} \mathrm{C}$ for 5 days. A spore inoculum was prepared by adding a loopful of spores from the slants to $5 \mathrm{ml}\left(1 \times 10^{5} \mathrm{cfu} / \mathrm{ml}\right)$ of sterile normal saline and shaken vigorously. 0.1 $\mathrm{ml}(\mathrm{v} / \mathrm{v})$ of the inoculum was used to inoculate fermentation medium. The substrate medium was prepared by adding the soluble pectin at the rate of $1 \%$ in the mineral solution and $30 \mathrm{ml}$ of it was taken in each $100 \mathrm{ml}$ Erlenmeyer flask. The cotton plugged flasks were autoclaved at $121^{\circ} \mathrm{C}$ for $20 \mathrm{~min}$, cooled to room temperature and inoculated with 0.1 $\mathrm{ml}$ of inoculum, mixed thoroughly by gently tapping the flasks on the palm of the hand and were incubated at $30^{\circ} \mathrm{C}$ for different incubation periods. After completion of the incubation period, the contents of the flasks were filtered through a perforated funnel and centrifuged to get the clear culture filtrate. The filtrate was employed for the estimation of the activities of pectinases.

\section{Enzyme activity measurements}

Polygalacturonase activity: To determine the polygalacturonase activity we measured the amount of reducing sugars such as galacturonic acid released from non esterified pectin, hydrolysed in the reaction mixture [16]. The reaction mixture consists of $2 \mathrm{ml}$ of $1 \%$ buffered solution of poly- galacturonate in phosphate citrate buffer ( $\mathrm{pH}$ 5.5). Further, $0.5 \mathrm{ml}$ of enzyme prepared was incubated at $30^{\circ} \mathrm{C}$ and samples were withdrawn at 0 and $30 \mathrm{~min}$. The amount of reducing sugars was estimated using -Somoygi [14] method. The enzyme activity was expressed in micromoles of the reducing sugars liberated $/ \mathrm{min} / \mathrm{ml}$ of enzyme prepared.

Pectin methyl esterase activity: To determine the pectin methyl esterase activity we measured the increase in acidity after the hydrolysis of methyl esters of pectin from the enzymes prepared. $5 \mathrm{ml}$ of buffered pectin substrate was incubated with $1 \mathrm{ml}$ of enzyme and $2 \mathrm{ml}$ of samples withdrawn at 0 and $60 \mathrm{~min}$ were titrated against $0.01 \mathrm{~N}$ sodium hydroxide to determine the amount of acid released. The enzyme activity was expressed as the micro-equivalents of acid released/min/ $\mathrm{ml}$ of enzyme preparation.

The enzyme activities are presented as mean $\pm \mathrm{SE}$ of all the values.
The results of enzyme production were analysed statistically using student's t- test.

\section{Microscopy}

Morphology of fungal hyphae and conidia was assessed by direct observation of fresh mycelial samples and spore size was recorded using micrometer. The production of sporulation structures was assessed by direct observation of fresh mycelial samples.

\section{Results}

The study was conducted with nine substrates including orange peel, pomegranate, tamarind seed powder, carrot, groundnut, soil, waste water, apple baggasse and bread. The strong effect of spore size on the production of PG was clearly observed (Table 1 and 2, Figure 1). The present investigation revealed highest amount of PG $(2.29 \pm 0.05)$ and PME $(0.73 \pm 0.08)$ production on orange peel amongst the nine agro waste sources by Aspergillus niger with smallest spore size $(5.49 \pm 2.56 \mu \mathrm{m})$ (Table 1, Figure 1, Figure $2 \mathrm{c}$ and $3 \mathrm{c})$. Isolated colonies of strains from orange peel were observed with $4 \pm 0.7 \mathrm{~cm}$ conidiophore size and $8 \pm 0.3 \mathrm{~cm}$ height of conidial stalk (Figure $2 \mathrm{c}$ and $3 \mathrm{c}$ ). However the maximum height of conidial stalk $(11 \pm 0.9 \mathrm{~cm})$ was observed in case of pomegranate with the conidiophore size of $5 \pm 0.5 \mathrm{~cm}$., showing isolated colonies. The spore size $6.25 \pm 2.86 \mu \mathrm{m}$ was comparatively more than the strain grown on orange peel hence showed subsequent reduction in the level of PG and PME $(1.18 \pm 0.04 ; 0.38 \pm 0.02 \mu \mathrm{moles} / \mathrm{ml} / \mathrm{min}$ ) (Table $1 \& 2$, Figure 1). Highest amount of PG and PME activity of orange

\begin{tabular}{|l|l|c|c|c|}
\hline S.No. & Isolates & $\begin{array}{c}\text { Spore } \\
\text { Size }(\boldsymbol{\mu m})\end{array}$ & $\begin{array}{c}\text { PG }(\boldsymbol{\mu m o l e s} / \\
\mathbf{m i n} / \mathbf{m l})\end{array}$ & PME $(\boldsymbol{\mu m o l e s} / \mathbf{m i n} / \mathrm{ml})$ \\
\hline 1. & Orange peel & $5.49 \pm 2.56$ & $2.29 \pm 0.05$ & $0.73 \pm 0.08$ \\
\hline 2. & $\begin{array}{l}\text { Tamarind seed } \\
\text { powder }\end{array}$ & $5.65 \pm 2.93$ & $1.76 \pm 0.03$ & $0.37 \pm 0.05$ \\
\hline $\mathbf{3 .}$ & Groundnut & $5.80 \pm 2.10$ & $0.95 \pm 0.06$ & $0.44 \pm 0.04$ \\
\hline $\mathbf{4 .}$ & Carrot & $6.12 \pm 3.16$ & $1.65 \pm 0.20$ & $0.36 \pm 0.09$ \\
\hline $\mathbf{5 .}$ & $\begin{array}{l}\text { Pomegranate } \\
\text { peel }\end{array}$ & $6.25 \pm 2.86$ & $1.18 \pm 0.04$ & $0.38 \pm 0.02$ \\
\hline $\mathbf{6 .}$ & Apple baggasse & $8.45 \pm 2.90$ & $0.62 \pm 0.07$ & $0.16 \pm 0.03$ \\
\hline 7. & Soil & $5.53 \pm 2.50$ & $2.19 \pm 0.06$ & $0.11 \pm 0.06$ \\
\hline $\mathbf{8 .}$ & Bread & $7.00 \pm 1.9$ & $0.76 \pm 0.06$ & $0.24 \pm 0.06$ \\
\hline $\mathbf{9 .}$ & Waste water & $8.50 \pm 2.43$ & $0.62 \pm 0.03$ & $0.18 \pm 0.05$ \\
\hline
\end{tabular}

Table 1: Quantitative estimation of pectinase production in relation to its spore size by Aspergillus niger.

\begin{tabular}{|c|c|c|c|c|}
\hline $\begin{array}{l}\text { Sr. } \\
\text { No. }\end{array}$ & Source & Colony formation & $\begin{array}{l}\text { Conidiophores } \\
\text { size }\end{array}$ & $\begin{array}{l}\text { Height of } \\
\text { conidial stalk }\end{array}$ \\
\hline 1 & $\begin{array}{l}\text { Apple } \\
\text { baggasse }\end{array}$ & Dense and crumpled & $4 \pm 0.4 \mathrm{~cm}$ & $10 \pm 0.7 \mathrm{~cm}$ \\
\hline 2 & $\begin{array}{l}\text { Pomegranate } \\
\text { peel }\end{array}$ & $\begin{array}{l}\text { Isolated and not } \\
\text { crumpled }\end{array}$ & $5 \pm 0.5 \mathrm{~cm}$ & $11 \pm 0.9 \mathrm{~cm}$ \\
\hline 3 & Orange peel & $\begin{array}{l}\text { Isolated and not } \\
\text { crumpled }\end{array}$ & $4 \pm 0.7 \mathrm{~cm}$ & $8 \pm 0.3 \mathrm{~cm}$ \\
\hline 4 & $\begin{array}{l}\text { Tamarind } \\
\text { seed powder }\end{array}$ & Isolated and crumpled & $1.5 \pm 0.3 \mathrm{~cm}$ & $5 \pm 0.3 \mathrm{~cm}$ \\
\hline 5 & Carrot & $\begin{array}{l}\text { Isolated and slightly } \\
\text { crumpled }\end{array}$ & $2 \pm 0.8 \mathrm{~cm}$ & $6 \pm 0.6 \mathrm{~cm}$ \\
\hline 6 & Groundnut & $\begin{array}{l}\text { A few Isolated and } \\
\text { crumpled }\end{array}$ & $3 \pm 0.3 \mathrm{~cm}$ & $8 \pm 0.7 \mathrm{~cm}$ \\
\hline 7 & Soil sample & Small and Dense & $1.8 \pm 0.3 \mathrm{~cm}$ & $7 \pm 0.3 \mathrm{~cm}$ \\
\hline 8 & Waste water & $\begin{array}{l}\text { Isolated and slightly } \\
\text { crumpled }\end{array}$ & $1.6 \pm 0.2 \mathrm{~cm}$ & $7 \pm 0.7 \mathrm{~cm}$ \\
\hline 9 & Bread & Small and Dense & $1.7 \pm 0.2 \mathrm{~cm}$ & $3 \pm 0.4 \mathrm{~cm}$ \\
\hline
\end{tabular}

Table: 2: Qualitative estimation of colony, conidiophores size and their height of Azospirillum niger 
Citation: Sharma NR, Sasankan A, Soni G (2011) Preliminary Study on Morphological Diversity of Aspergillus niger Strains Grown on Various Agri waste in Relation to Enzyme Production. J Microbial Biochem Technol 3: 084-087. doi:10.4172/1948-5948.1000056

peel, was followed by PG and PME activity of tamarind seed powder $(1.76 \pm 0.03 \mu \mathrm{moles} / \mathrm{ml} / \mathrm{min}, 0.37 \pm 0.05 \mu \mathrm{moles} / \mathrm{ml} / \mathrm{min})$ and soil sample $(2.19 \pm 0.06 \mu \mathrm{moles} / \mathrm{ml} / \mathrm{min}, 0.11 \pm 0.06 \mu \mathrm{moles} / \mathrm{ml} / \mathrm{min})$ with spore size of $5.65 \pm 2.93$ and $5.53 \pm 2.50 \mu \mathrm{m}$ respectively. Least value of PME was observed in case of soil sample. The size of conidiophores of soil strain $(1.8 \pm 0.3 \mathrm{~cm})$ was comparatively less than orange peel grown strain $(4 \pm 0.7 \mathrm{~cm})$. The spread of colonies was isolated and crumpled in the strains grown on tamarind seed $(1.5 \pm 0.3 \mathrm{~cm}, 5 \pm 0.3 \mathrm{~cm})$ and groundnut $(3 \pm 0.3 \mathrm{~cm}, 8 \pm 0.7 \mathrm{~cm})$ with large variation in size of conidiophores and height of conidial stalk (Figure 2 and 3). The pattern of colonies of strains on apple baggasse and waste water was dense and isolated respectively. However, level of pectinases and other parameters studied were near in both types of strains (Table $1 \& 2$, Figure 1) indicated minimum level of PG and maximum spore size in case of waste water grown strain $(8.50 \pm 2.43 \mu \mathrm{m})$. The strain grown on carrot showed isolated and slightly crumpled colonies with the dimension of $2 \pm 0.8 \mathrm{~cm}$ of conidiophores and $6 \pm 0.6 \mathrm{~cm}$ height of conidial stalk. The spore size was $6.12 \pm 3.16 \mu \mathrm{m}$ with PG and PME activity measured as $1.65 \pm 0.20$ and $0.36 \pm 0.09 \mu \mathrm{moles} / \mathrm{ml} / \mathrm{min}$ (Table 1, Figure 1).

\section{Discussion}

Microbial production of pectinases has been extensively studied [23,5] in actinomycetes [12] Aspergillus flavus and Aspergillus sp. [22]. The morphological form of the cultivated fungus is an important factor in the production of pectinases. In submerged culture the morphology of filamentous microorganisms varies between two extreme forms, pellets and free filaments depending on culture conditions and the genotype of the strain. According to many reports, mycelial morphology is crucial to the process of fermentation, not only in relation to the shape of the hyphae themselves and the aggregation into microscopic clumps (micro-morphology), but also in the pelleted form of growth (macro-morphology). Studies revealed, free mycelia are required for increased productivity as the production of penicillin from Penicillium chrysogenum [9] Regarding pellet morphologies as a prerequisite for increased productivities, methodologies for pellet production for several microorganisms have been suggested [1]. In the present study PG activity was found reduced with the increase in spore size (Table 1, Figure 1) that might be attributed to less availability of substrate and type of carbon source. However, the mechanism by which the spore morphology acts on the production of pectic enzyme is not known. On the other hand PME activity was more or less similar with increase

\section{Pectinase production in relation to spore size}

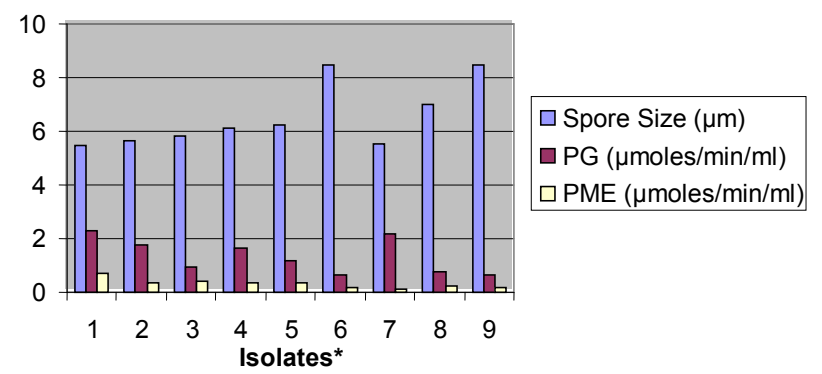

* 1: Orange Peel; 2: Tamarind seed powder; 3: Groundnut; 4: Carrot; 5: Pomegranate Peel; 6: Apple baggasse; 7: Soil; 8: Bread; 9: Waste Water

Figure 1: Pectinase production in relation to spore size.

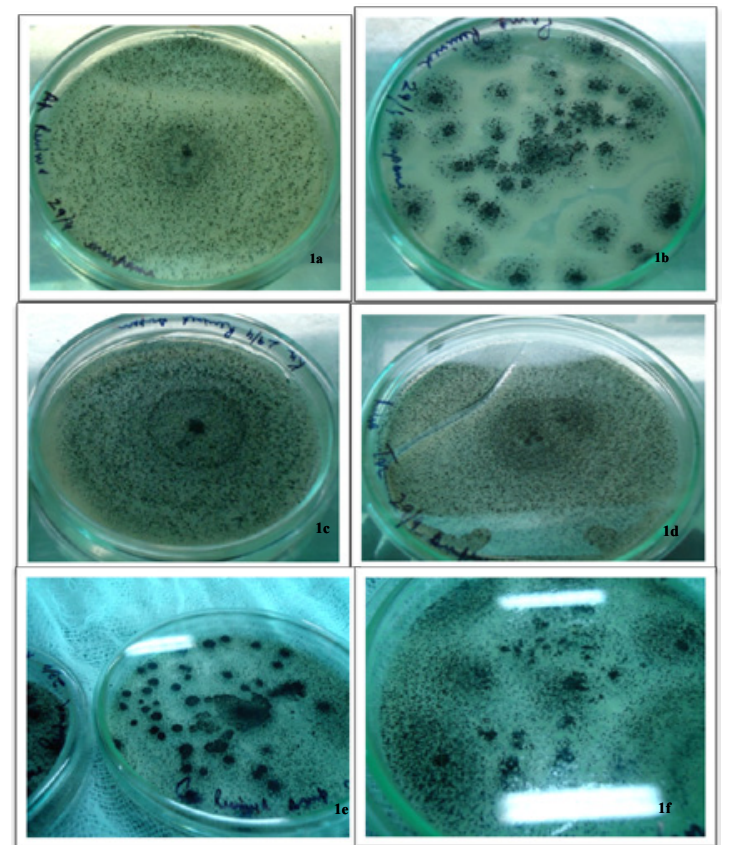

Figure 2: Represents colony shape and size of the A. niger, 1(a): Apple; 1(b): Pome granate; 1(c) Orange; 1(d) Tamarind; 1(e) Carrot ; 1(f): Groundnut.

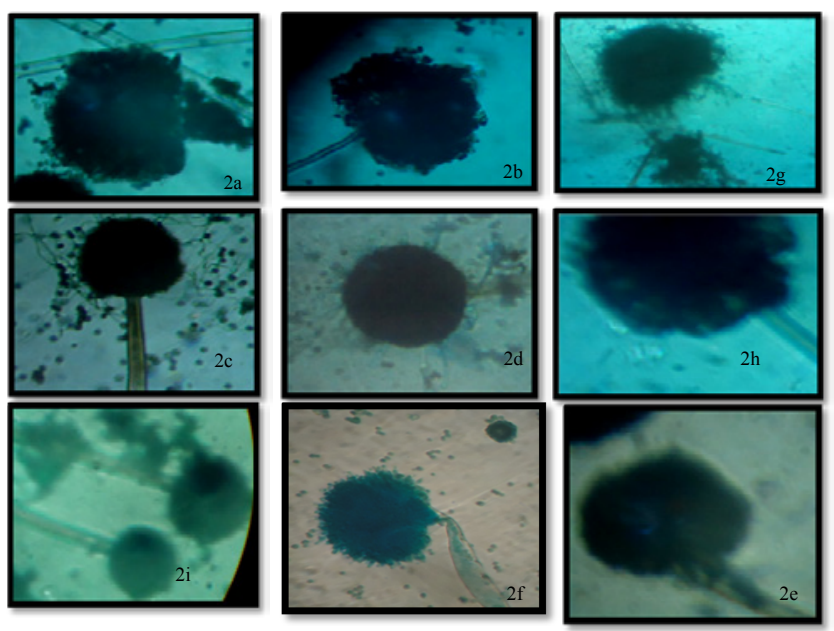

Figure 3: Qualitative representation of conidiospore production onto 2(a): Pomegranate; 2(b):Apple; 2(c):Orange; 2(d):Tamarind Seed; 2(e):Carrot; 2(f):Groundnut; 2(g):Soil Sample; 2(h):Waste Water; 2(i):Bread

in spore size (Table 1, Figure 1) and there is no such correlation of PME production with the spore morphology. The colonies were almost small and dense in soil and bread isolates. Reports on the preferred morphology are often contradictory since each one of the two extreme forms such as pellets and filaments have their own characteristics concerning cell physiology, growth kinetics, nutrient consumption and broth rheology [16] As per study, drawback of pelleted suspensions is that cell growth- and consequent metabolic activity-occurs at the surface only, where contact with oxygen and medium nutrients is adequate, while the cells inside the pellets respond to a very different environment. Further into pellets, mass transfer limitation gradually occurs and cells become subjected to autolysis [15]. Only a fraction 
Citation: Sharma NR, Sasankan A, Soni G (2011) Preliminary Study on Morphological Diversity of Aspergillus niger Strains Grown on Various Agri waste in Relation to Enzyme Production. J Microbial Biochem Technol 3: 084-087. doi:10.4172/1948-5948.1000056

of the mycelium takes part in biosynthesis of metabolites when this requires for example elevated dissolved oxygen concentrations. Pellet formation results in striking effects on polygalacturonidase production by $A$. niger and its synthesis correlate well with the particular morphological type. The more compact the pellet, the greater the enzyme synthesis. Regardless the medium used, an increase of almost two orders of magnitude in the polygalacturonidase concentration and production rates between the diffuse mycelium and pellets was observed. Similar increases were observed in a-galactosidase synthesis by mycelial pellets of Mortierella vinacea and nikkomycin production by Streptomyces tendae [4]. Such phenomena were related to diffusion limitations in pellets, which either reduce the extent of catabolic repression in pellets or limit the oxygen supply preventing thus an oxidative inactivation of specific sets of enzymes, as well as to the existence of additional factors, such as gradients of metabolic products in pellets serving as biological signals (modulators). The colony formed by the strains from tamarind seed powder, groundnut, carrot and waste water was isolated and slightly crumpled with slight variation in size of conidiophores and height of conidial stalk. The increase in size of spores caused depletion in PG and PME except groundnut where the spore size did not affect much on the concentration of pectinases. It appears that the enzyme synthesis related to mycelium structure is independent of the mechanism which regulates the level of pectinase synthesis within a specific morphological structure. Altogether, the relationship between physiology, morphology and enzyme production, if any, is poorly understood.

\section{Conclusion}

Our results using $A$. niger from various agro wastes, showed enhanced enzyme production and somewhat linear relationship between enzyme production (Pectinases) and morphology (spore size). However, there is a scope for further study on optimization of the conditions for increased production of pectinases from agrowastes and development of markers for preliminary screening of strains containing significant amount of pectinases.

\section{Acknowledgements}

The authors are sincerely grateful to Lovely Professional University, Jalandhar, India for encouragement and financial support. Further, authors also acknowledge the contribution of Dr. V.K. Mishra.

\section{References}

1. Atkinson B, Daoud IS (1976) Microbial flocs and flocculation in fermentation process engineering. Adv Biochem Eng 4: 41-124

2. Angayarkanni J, Palaniswamy M, Murugesan S, Swaminathan K (2002) Improvement of tea leaves fermentation with Aspergillus spp. pectinase. $J$ Biosci Bioengg 94: 299-303

3. Bennett JW, Klich MA (2003) Mycotoxins. Clinical Microbiology Review 16: 497 $-516$

4. Braun S, Vecht-Lifshitz SE (1991) Mycelial morphology and metabolite production. Tibtech 9: 63-68

5. Bruhlmann F, Kim KS, Zimmerman W, Fiechter A (1994) Pectinolytic enzymes from actinomycetes for the degumming of ramie bast fibers. Appl Env Microbiol 60: $2107-2112$

6. Dixon DM, Walsh TJ (1992) Human Pathogenesis. In: Bennett JW, Klich MA (ed) Aspergillus Biology and Industrial Applications. Boston MA, ButterworthHeinemann, pp 109-119

7. Ferret E, Simeon JH, Molin P, Jorquera H, Acuna G, et al. (1999) Macroscopic growth of filamentous fungi on solid substrate explained by a microscopic approach. Biotechnology and Bioengineering 65:512-522

8. Gonzalez M, Alba M, Gonzalez V, Gustavo Fernandez Francisco J, Loera O (2004) Effect of water activity on invertase production in solid state fermentation by improved diploid strains of Aspergillus niger. Process Biochemistry 39 : 2085-2090

9. Hemmersdorfer H, Leuchtenberger A, Wardsack C, Ruttloff H (1987) Influence of culture conditions on mycelial structure and polygalactorunidase synthesis of Aspergillus niger. J Basic Microbiol 27: 309-315

10. Kashyap DR, Vohra PK, Chopra S, Tewari R (2001) Applications of pectinases in the commercial sector. Bioresour Technol 77: 215-227

11. Mccarthy TC, Lalor E, Hanniffy O, Savage AV, Tuohy MG (2005) Comparison of wild-type and UV-mutant $\beta$-glucanase-producing strains of Talaromyces emersonii with potential in brewing applications. J Industrial Microbiology and Biotechnology 32: 125-134.

12. Mellon JE, Cotty PJ (2004) Expression of pectinase activity among Aspergillus flavus isolates from southwestern and southeastern United States. Mycopathologia1 57: 333-338.

13. Metz B, Kossen WF, Van Suijdam JC (1979) The rheology of mould suspensions. Adv Biochem Eng 11: 103-156.

14. Nelson N (1944) Photometric adaptation of the Somogyi method for the determination of glucose. J Biol Chem 153: 375-380.

15. Papagianni M (2004) Fungal morphology and metabolite production in submerged mycelial processes. Biotechnol Adv 22: 189-259

16. Papagianni M (2006) Morphological development of Aspergillus niger in submerged citric acid fermentation as a function of the spore inoculum level. Microbial Cell Factories 5: 1-12

17. Perrone G, Mulè G, Susca A, Battilani P, Pietri A, et al. (2006) Ochratoxin A production and AFLP analysis of Aspergillus carbonarius, Aspergillus tubingensis, and Aspergillus niger strains isolated from grapes in Italy. App Environ Microbiol 72: 680-685

18. Perrone G, Susca A, Cozzi G, Ehrlich K, Varga J, et al. (2007) Biodiversity of Aspergillus species in some important agricultural products. Studies in Mycology 59: 53-66

19. Ponsone ML, Combina M, Dalcero A, Chulze SN (2007) Ochratoxin A and ochratoxigenic Aspergillus species in Argentinean wine grapes cultivated under organic and non-organic systems. Int J Food Microbiol 114: 131-135

20. Rangarajan $V$, Rajasekharan $M$, Ravichandran $R$, Sriganesh $K$, Vaitheeswaran $V(2010)$ Pectinase Production from Orange Peel Extract and Dried Orange Peel Solid as Substrates Using Aspergillus niger. International Journal of Biotechnology and Biochemistry 6: 441-449

21. Reid I, Ricard M (2000) Pectinase in paper making: solving retention problems in mechanical pulps bleached with hydrogen peroxide Enzyme Microb Technol 26: $115-123$

22. Samson RA, Houbraken JAMP, Kuijpers AFA, Frank JM, et al. (2004) New ochratoxin $\mathrm{A}$ or sclerotium producing species in Aspergillus section Nigri. Studies in Mycology 50: 45-61

23. Torres EF, Sepulveda TV, Gonzalez GV (2006) Production of hydrolytic depolymerising pectinases. Food Technol Biotechnol 44: 221-227

24. Trinci APJ (1973) The hyphal Growth Unit of wild type and spreading colonia mutants of Neurospora crassa. Arch Microbiol 91: 127-136. 